\title{
SUMMARY
}

Lazer-Pankiv Olesia. Factors of Improving Learning Motivation in the Process of Ancient Greek Linguosociocultural Competence Formation.

The article is devoted to the analysis of factors of learning motivation increase in the process of Ancient Greek linguosociocultural competence formation. The peculiarities of the modern educational paradigm and the place of Ancient Greek language in it are outlined, in particular, the causes of the crisis state of modern classical philology and its manifestations in the higher education system are analysed. The features of the Ancient Greek language learning process organization, ways and methods of improving the quality of its teaching are also considered, among which the priority is to bring the Ancient Greek language teaching process to an interdisciplinary level and to introduce new and varied techniques and teaching methods in order to increase the level of learning motivation. Particular attention is paid to the most important features of the subjects of study, which the level of learning Ancient Greek motivation depends on, in particular, the emphasis is placed on the inextricable link of motivation with the emotional sphere and with the interest of the subjects of learning to the object of study. The proposed study also analyses the specificity of ancient Greek (in particular, its grammatical features) and the degree of difficulty in mastering it as an important factor in the possible negative impact on learning Ancient Greek motivation. Particular attention is given to outlining the importance of ancient Greek for the professional training of students as a whole. The utilitarian and pragmatic motives of learning Ancient Greek (as well as other classical languages) are not clearly expressed and defined, that's why it is important to focus on the procedural and content related motives: the important role of learning Ancient Greek for a) self-development and self-improvement; b) a better understanding of their own language; c) comprehension of all ancient intellectual heritage; d) formation of a multicultural, tolerant personality. Possibilities of using the process of linguosociocultural competence formation as a means of increasing Ancient Greek learning motivation are highlighted taking into consideration all the above mentioned factors.

Keywords: learning motivation, linguosociocultural competence, Ancient Greek language, modern educational paradigm, subjects of educational activity.

удк 364-43:364.6

Марина Лехолетова

Київський університет імені Бориса Грінченка ORCID ID 0000-0003-4055-991X

Тетяна Лях

Київський університет імені Бориса Грінченка ORCID ID 0000-0002-8807-0497

DOI 10.24139/2312-5993/2020.02/135-144

\section{ПІДГОТОВКА МАЙБУТНІХ СОЦІАЛЬНИХ ПРАЦІВНИКІВ ДО АДВОКАЦІЙНОї ДІЯЛЬНОСТІ}

Стаття присвячена розгляду сутності представничтва інтересів (адвокації), ролі адвокації в роботі соціальних прачівників. здійснено опис програми підготовки майбутніх соціальних працівників до адвокаційної діяльності. Подано зміст, мету та завдання програми навчальної дисципліни «Технології соціальної адвокації для студентів спеціальності «Соціальна робота».

До ключових тем цієї програми віднесено такі: адвокаційна діяльність соціального працівника; методи соціальної адвокації; організація адвокаційної кампанії; соціальна адвокація як інструмент захисту прав та свобод громадян. 
Наведено приклади практичних робіт та самостійних завдань, мета яких полягає в закріпленні студентами знань із пройденого теоретичного матеріалу.

Ключові слова: сочіальний працівник, соціальна робота, адвокація, адвокаційна діяльність, соціальна послуга представництва інтересів, технології соціальної адвокації.

Постановка проблеми. Адвокаційна діяльність соціальних працівників набуває все більшої актуальності. Процеси децентралізації влади спричинили реформування структури соціальних служб, вивели громадські об єднання соціальної сфери в повноправні суб’єкти соціальної роботи на рівні громади. Усе частіше соціальні працівники не просто долучаються до адвокаційних кампаній у найкращих інтересах своїх клієнтів, а й самі ініціюють, розробляють та координують їх. Тому розвиток такої професійної компетентності в майбутніх соціальних працівників $\epsilon$ важливим завданням освітніх програм у закладах вищої освіти.

Соціальні працівники в роботі з різними категоріями отримувачів послуг виступають посередниками, організаторами дій, спрямованих на здійснення впливу на певних осіб або організацій, що приймають рішення, контролюють дотримання чинного законодавства, прав та свобод.

На сьогодні соціальна адвокація і адвокаційна діяльність соціальних працівників в Україні не врегульовані окремим законодавчим актом. Проте різні аспекти відносин у цій сфері вибірково регулюються такими законами України: «Про органи і служби у справах дітей та спеціальні установи для дітей» (2017), «Про звернення громадян» (2018), «Про громадські об'єднання» (2018), «Про забезпечення організаційно-правових умов соціального захисту дітей-сиріт та дітей, позбавлених батьківського піклування» (2018), «Про попередження насильства в сім'ї» (2018), «Про доступ до публічної інформації» (2019), «Про запобігання корупції» (2019), «Про місцеве самоврядування в Україні» (2019), «Про соціальні послуги» (2019), «Про охорону дитинства» (2019).

Аналіз актуальних досліджень. Вивчення проблеми адвокації як складової професійної діяльності фахівців соціальної сфери $\epsilon$ одним із напрямів сучасних досліджень. Серед проблем, які порушуються в них, є: представництво інтересів людей із інвалідністю як метод соціальної роботи (Гончар, 2019); партнерство державного та недержавного суспільних секторів як ефективний механізм управління у сфері надання соціальних послуг у країнах Євросоюзу (Дубич, 2013); компетентність соціального працівника у сприянні міжвідомчій взаємодії щодо соціально-правового захисту особистості (Лісовець, 2016); представництво інтересів людей, які живуть із ВІЛ/СНІДом в Україні (Скрипка, 2014); передумови інституціалізації медіакомунікації у сфері вирішення соціальних проблем (Шендеровський, 2013).

Проте, аналіз наукових досліджень дає змогу зробити висновок, що проблема підготовки майбутніх соціальних працівників до адвокаційної діяльності не була предметом окремого дослідження. 
Мета статті: розглянути роль адвокації в роботі соціальних працівників та висвітлити досвід підготовки майбутніх соціальних працівників до адвокаційної діяльності в Інституті людини Київського університету імені Бориса Грінченка.

Методи дослідження. Для вирішення поставлених завдань було використано такі методи: порівняльний аналіз психолого-педагогічних іноземних та вітчизняних наукових джерел із досліджуваної проблеми; вивчення й узагальнення педагогічного досвіду у сфері професійної підготовки майбутніх соціальних працівників у закладах вищої освіти.

Виклад основного матеріалу. Найчастіше адвокаційну діяльність соціального працівника ототожнюють із представництвом інтересів і розглядають лише в межах індивідуальної соціальної роботи, яка використовується здебільшого для вирішення певних юридичних питань (Гончар, 2019; Лісовець, 2016).

Згідно з Державним стандартом соціальної послуги представництва інтересів (2016), термін «соціальна послуга представництва інтересів» розглядається як надання допомоги особам, сім'ям, окремим соціальним групам, які перебувають у складних життєвих обставинах, шляхом здійснення заходів, спрямованих на подолання/пом'якшення складних життєвих обставин, згідно з визначеними потребами (Наказ Міністерства соціальної політики України, 2016).

У дослідженнях зарубіжних науковців представництво інтересів розглядається як: вплив на прийняття рішень із метою розробки, створення або зміни політики й установлення і підтримка програм та послуг (Advocacy guide: HIV/AIDS prevention among injecting drug user, 2004); вплив на користь організацій та груп у межах правової влади та політичної структури (Essays, 2018); справедливий та рівноправний доступ до державних послуг (McLaughlin, 2009); динамічний процес ведення переговорів від імені індивіда, який опинився у складних життєвих обставинах (Weafer, 2003).

у зв'язку з потребою суспільства в компетентних фахівцях соціальної сфери, які $б$ розробляли дієві адвокаційні стратегії для захисту прав та інтересів уразливих категорій отримувачів соціальних послуг, з 01.09.2019 року в Київському університеті імені Бориса Грінченка було введено в дію нову освітню програму 231.00 .04 «Соціальна адвокація», розроблену на підставі стандарту вищої освіти за спеціальністю 231 Соціальна робота для першого (бакалаврського) рівня вищої освіти, затвердженого Міністерством освіти та науки України (2019 р.) (Наказ Міністерства освіти та науки України, 2019).

Основним фокусом освітньої програми $\epsilon$ акцент на підготовку менеджера соціальної сфери, здатного моделювати та впроваджувати технології соціальної роботи; налагоджувати результативну соціальну комунікацію між різними суб'єктами соціальної роботи в громаді 
(Освітньо-професійна програма 231.00.04 Соціальна адвокація для студентів першого (бакалаврського) рівня вищої освіти, 2019).

Однією з ключових дисциплін у навчальному плані підготовки студентів за цією освітньою програмою $\epsilon$ «Технології соціальної адвокації», яку студенти вивчають на першому курсі професійної підготовки (Лях та Лехолетова, 2019).

Метою викладання дисципліни «Технології соціальної адвокації» $€$ : сприяти розвиткові професійної компетентності майбутніх соціальних працівників, засвоєнню теоретичних знань із технологій соціальної адвокації, практичних умінь із розробки адвокаційних кампаній у соціальній сфері та управління ними.

у процесі вивчення дисципліни «Технології соціальної адвокації» майбутні соціальні працівники здобувають низку компетентностей, а саме: здатність добирати й застосовувати різні методи соціальної адвокації, розробляти програми адвокаційних кампаній; здатність застосовувати знання у практичних ситуаціях та приймати обґрунтовані рішення; здатність ініціювати соціальні зміни, спрямовані на покращення соціального добробуту.

Відповідно до стандарту вищої освіти та освітньої програми, результатами навчання за дисципліною є вміння:

- критично аналізувати й оцінювати чинну соціальну політику країни, соціально-політичні процеси на загальнодержавному, регіональному та місцевому рівнях;

- використовувати форми та методи адвокаційних кампаній залежно від викликів соціальної реальності;

- застосовувати методи менеджменту для організації власної професійної діяльності та управління діяльністю соціальних робітників і волонтерів, іншого персоналу;

- визначати потенційні групи ризику споживачів соціальних послуг, які потребують адвокації соціального працівника в різних установах.

Програма складається з чотирьох модулів, що відповідає чотирьом кредитам (120 год.). Теоретична частина курсу містить 4 теми і розрахована на 10 годин лекційних занять, а саме:

1. Адвокаційна діяльність соціального працівника (2 год.).

2. Методи соціальної адвокації (2 год.).

3. Організація адвокаційної кампанії (4 год.).

4. Соціальна адвокація як інструмент захисту прав та свобод громадян (2 год.).

Практичну частину розраховано на 10 год. семінарських і 22 год. практичних занять. До кожного модуля є одна самостійна робота, яка розрахована на 40 год. (10 год. кожна) та один модульний контроль, розрахований на 8 годин (2 год. кожен). Оскільки вивчення дисципліни завершується іспитом, тому на підготовку та проходження контрольних заходів відведено 30 год. 
Розглянемо детальніше тематику модулів та перелік завдань, які виконують студенти під час вивчення навчального матеріалу. До першого модулю «Теоретико-методологічна сутність адвокації віднесено дві теми.

Тема 1. «Адвокаційна діяльність соціального працівника», під час якої студенти вивчають: актуальність адвокаційної діяльності соціального працівника в Україні; стратегії адвокації; адвокаційну діяльність (рівні, ознаки, принципи, виконавці); фактори, які впливають на стратегію авокаційної діяльності; планування альтернативних стратегій розв'язання соціальних проблем цільових груп; пілотні програми адвокаційної діяльності; правове соціальне адвокатування.

Тема 2. «Методи соціальної адвокації», де розглядаються аналіз цілей, вибір альтернатив, основи аналізу політики, класифікація методів адвокації, методи і прийоми обробки експертної інформації.

Другий модуль «Основи стратегічного планування кампанії» націлений на вивчення етапів планування та організації адвокаційної кампанії. Зокрема, розглядаються види, принципи, етапи організації та проведення адвокаційних кампаній для цільових груп: визначення проблеми, з якою стикається цільова група, аналіз наслідків, визначення причин, адвокаційної мети та завдань; визначення потенційних партнерів; аналіз необхідних ресурсів та підготовка робочого плану.

До третього модулю теоретичного матеріалу не передбачено. Весь модуль побудовано на практичних заняттях, де студенти закріплюють отримані знання з пройденого теоретичного матеріалу та відпрацьовують навички розробки адвокаційної кампанії.

Четвертий модуль «Публічна складова адвокації» присвячений вивченню теми «Соціальна адвокація як інструмент захисту прав та свобод громадян» де студенти розглядають: формальне соціальне адвокатування; побудову та підтримку партнерів; визначення стейкхолдерів адвокаційної діяльності; складання карти та матриці стейкхолдерів; моніторинг розвитку справ та успіху адвокації у сфері соціальної роботи.

Готуючись до семінарських занять із дисципліни, студенти відпрацьовують навички дослідницького пошуку окремих теоретичних положень навчальної дисципліни, створюють презентацію у вигляді документу Microsoft PowerPoint з розкриттям змісту тем, які винесені на семінарське заняття. Під час семінарських занять перевага надається дискусійним обговоренням проблемних питань, коли студенти мають змогу вільно висловлювати свої думки. Такий формат заняття сприяє розвиткові активної особистісної позиції з досліджуваного питання і стимулює активність мислення студентів.

Для самостійної роботи студентам пропонуються завдання з тем, які безпосередньо пов'язані з матеріалом, що вивчається на поточних заняттях та мають сприяти розвиткові вмінь орієнтуватися в потоці наукової інфор- 
мації, незалежності мислення, формування власного погляду на питання, що вивчається. Розглянемо детальніше завдання самостійної роботи студентів.

Завданням першої самостійної роботи на тему «Адвокаційна діяльність фахівців соціальної роботи в Україні та за кордоном» $\epsilon$ аналіз напрямів адвокаційної діяльності фахівців Державних громадських організацій соціальної сфери в Україні та закордоном.

Метою другої самостійної роботи є пошук проблем і суперечностей у нормативно-правових актах, що призводять до дискримінації певних груп клієнтів соціальної роботи й потребують адвокації їхніх інтересів. При цьому студенти можуть здійснювати не лише аналіз вітчизняних нормативно-правових актів, але й порівнювати сучасний стан національного законодавства України в галузі, яку вони обрали, та оцінку стану його відповідності міжнародним стандартам у галузі захисту прав людини і забезпечення охорони громадського здоров'я.

Виконуючи третю самостійну роботу «Інтерв'ю для ЗМІ» перед студентами стоїть завдання обрати групу клієнтів соціальної роботи, інтереси яких вони лобіюватимуть (на вибір студентів) та підготуватися до інтерв'ю для засобів масової інформації в ролі представника обраної групи клієнтів.

Завданням четвертої самостійної роботи «Аналіз стейкхолдерів для цілей адвокаційної кампанії» $€$ : аналіз інтересів, оцінка важливості та впливовості стейкхолдерів, щодо визначеної проблеми (ступінь необхідності їх залучення для досягнення поставлених цілей у реалізації адвокаційної кампанії на державному рівні).

Для виконання практичних робіт із дисципліни студенти використовують напрацьовані матеріали самостійних робіт, оскільки всі завдання між собою пов'язані. Так, у ході перших двох практичних робіт студенти, розробляючи план адвокаційної кампанії та заходи ії інформаційного забезпечення, використовують матеріали другої самостійної роботи з визначення проблем(и) й суперечностей(ості) у нормативно-правових актах, що призводять до дискримінації обраної студентами групи клієнтів соціальної роботи.

Уміння правильно оцінити вплив політичної ситуації або законодавчого акту, а також їх застосування $€$ життєво важливим для роботи адвокасі. Ці навички можуть використовуватися захисниками інтересів, які працюють у межах системи ухвалення рішень (наприклад, члени комітетів), і тими, хто працює ззовні.

Також за програмою студенти відпрацьовують навички формулювання пропозиції; підготовки прес-релізів та прес-конференцій; застосування техніки переконання шляхом театралізованих вистав; організації громадських демонстрацій, флеш-мобів, бойкотів та пікетів; опису позицій стейкхолдерів стосовно визначеної проблеми; складання робочого плану адвокаційної кампанії та ін. 
Кожен модуль із дисципліни завершується написання модульної контрольної роботи, яка проходять у формі тестування (25 випадкових запитань із пройденого матеріалу відповідного модулю). Тестові завдання складаються з п'яти видів: із вибором відповіді Так/Hi; із вибором однієї правильної відповіді; із вибором двох або трьох правильних відповідей; на встановлення відповідності запропонованих наборів тверджень; на встановлення послідовності.

Семестровий контроль (екзамен) з дисципліни проводиться у вигляді письмової роботи, яка включає три завдання: теоретичне (тестові питання); теоретико-практичне та практичне. Кожен вид завдань має свої критерії оцінювання, а саме: тестові завдання - правильність відповіді на питання; теоретико-практичне завдання - чіткість, повнота та розгорнутість відповіді, визначення основних понять; творче осмислення набутих теоретичних знань, уміння використовувати теоретичні знання під час практичних завдань; практичне завдання - технологічна та методична грамотність, точність виконання практичного завдання.

Висновки та перспективи подальших наукових розвідок. Розроблений та впроваджений нами курс «Технології соціальної адвокації» охоплює актуальні питання технологій соціальної адвокації і може бути рекомендований для підготовки майбутніх соціальних працівників освітньої програми «Соціальна адвокація».

у результаті опанування курсу майбутні соціальні працівники оволодіють такими ключовими компетенціями, як: добирати й застосовувати різні методи соціальної адвокації, розробляти програми адвокаційних кампаній; застосовувати знання у практичних ситуаціях та приймати обґрунтовані рішення; ініціювати соціальні зміни, спрямовані на піднесення соціального добробуту.

Крім того, розроблена програма сприяє забезпеченню програмних результатів навчання, а саме вміння: критично аналізувати й оцінювати чинну соціальну політику країни, соціально-політичні процеси на загальнодержавному, регіональному та місцевому рівнях; використовувати форми та методи адвокаційних кампаній залежно від викликів соціальної реальності; застосовувати методи менеджменту для організації власної професійної діяльності та управління діяльністю соціальних робітників і волонтерів, іншого персоналу; визначати потенційні групи ризику споживачів соціальних послуг, які потребують адвокації соціального працівника в різних установах. Перспективи подальших розвідок ми вбачаємо у визначенні рівня сформованості знань, умінь та навичок адвокаційної діяльності майбутніми соціальними працівниками по завершенню вивчення курсу «Технології соціальної адвокації». 


\section{ЛITEPATУРА}

Гончар, І. Г. (2019). Представництво інтересів людей з інвалідністю у соціальній роботі. Науковий вісник Ужгородського університету. Серія:«Педагогіка. Соціальна poбoma», 1 (44), 33-37 (Honchar, I. H. (2019). Representing the interests of people with disabilities in social work. Uzhgorod University Scientific Bulletin. Series: «Pedagogy. Social work», 1 (44), 33-37).

Дубич, К. В. (2013). Партнерство державного та недержавного суспільних секторів як ефективний механізм управління у сфері надання соціальних послуг у країнах Євросоюзу. Державне управління: теорія та практика, 2, 117-128 (Dubych, K. V. (2013). Partnership between public and non-governmental public sectors as an effective governance mechanism in the field of social service provision in EU countries. Public administration: theory and practice, 2, 117-128).

Лісовець, О. В. (2016). Компетентність соціального працівника у сприянні міжвідомчій взаємодії щодо соціально-правового захисту особистості. Наукові записки Ніжинського державного університету ім. Миколи Гоголя. Психологопедагогічні науки, 1, 43-47 (Lisovets, 0. V. (2016). Competence of a social worker in promoting interagency cooperation on social and legal protection of the individual. Scientific Notes of Nizhyn State University named after M ykola Gogol. Psychological and pedagogical sciences, 1, 43-47).

Лях, Т. Л., Лехолетова, М. М. (2019). Технології соціальної адвокації: робоча програма навчальної дисципліни. К. : Київ. ун-т ім. Б. Грінченка. Режим доступу: http://elibrary.kubg.edu.ua/id/eprint/30529/1/Program \%D

0\%90dvocacy Liakh Lekholetova 2019.pdf (Liakh, T. L., Lekholetova, M. M. (2019). Technology of social advocacy: a work program of the discipline. Borys Grinchenko Kyiv University. Retrieved from: http://elibrary.kubg.edu.ua /id/eprint/30529/1/Program \%D0\%90dvocacy Liakh Lekholetova 2019.pdf).

Наказ Міністерства освіти та науки України «Про затвердження стандарту вищої освіти за спеціальністю 231 «Соціальна робота» для першого (бакалаврського) рівня вищої освіти» (2019). Режим доступу: https:// mon.gov.ua/storage/app/media/vishchaosvita/zatverdzeni\%20standarty/2019/04/25 1231-sotsialna-robota-bakalavr.pdf. (Order of the M inistry of Education and Science of Ukraine "On approval of the higher education standard in the specialty 231 "Social work" for the first (bachelor) level of higher education". (2019). Retrieved from: https://mon.gov.ua/storage/app/media /zatverdzeni\%20standarty/2019/04/25/231-sotsialna-robotabaka lavr.pdf).

Наказ Міністерства соціальної політики України «Про затвердження Державного стандарту соціальної послуги представництва інтересів» (2016). Режим доступу: http://zakon.rada.gov.ua/laws/show / z0127-16. (Order of the Ministry of Social Policy of Ukraine "On approval of the State standard of social service of representation of interests". (2016). Retrieved from: http://zakon.rada.gov.ua/ laws/show/z0127-16).

Освітньо-професійна програма 231.00.04 Соціальна адвокація для студентів першого (бакалаврського) рівня вищої освіти (2019) / [Робоча група: Т. Л. Лях, С. В. Сапіга, Т. П. Спіріна]. К.: Київ. ун-т ім. Б. Грінченка. Режим доступу: http://kubg.edu.ua/images/stories/Departaments/vstupnikam

il/2019/OPP soc advokaciia.pdf. (Educational and professional program 231.00.04 Social advocacy for students of the first (bachelor) level of higher education (2019). T. L. Liakh, S. V. Sapiha, T. P. Spirina. Borys Grinchenko Kyiv University. Retrieved from:

http://kubg.edu.ua/images/stories/Departa ments/vstupnikam/il/2019/OPP_soc_advokaciia.pdf). 
Скрипка, І.В. (2014). Практика колективного представництва інтересів в Україні (на прикладі людей, які живуть з ВІЛ/СНІДом). Наукові записки НаУКМА. Педагогічні, психологічні науки та сочіальна робота, 162, 62-67 (Skrypka, I. V. (2014). The practice of collective representation of interests in Ukraine (for example, people living with HIV/AIDS). NaUKMA Scientific Notes. Pedagogical, psychological sciences and social work, 162, 62-67).

Шендеровський, К. С. (2013). Передумови інституціалізації медіакомунікації у сфері вирішення соціальних проблем. Українське журналістикознавство, 14, 40-49 (Shenderovskyi, K. S. (2013). Prerequisites for institutionalization of media communication in the field of social problems. Ukrainian Journalism Studies, 14, 40-49).

Advocacy guide: HIV/AIDS prevention among injecting drug user. WHO. Geneva: World Health Organization, 2004. 120. Retrieved from: http:// www. who.int/hiv/pub/advocacy/en/advocacyguideen.pdf.

Essays, U. K. (2018). Advocacy in Social Work. Retrieved from https://www.ukessays. com/essays/social-work/definition-of-advocacy.php? vref $=1$.

M cLaughlin, A. M. (2009). Clinical Social Workers: Advocates for Social Justice. Advances in social work, 10 (1), 51-68. DOI: https:// doi.org/10.18060/209

Weafer, J. A. (2003). Jigsaw of advocacy: a research report. Comhairle. Edited by Máiríde Woods.

\section{PEЗЮME}

Лехолетова Марина, Лях Татьяна. Подготовка будущих социальных работников к адвокационной деятельности.

Статья посвящена рассмотрению сущности представительства интересов (адвокации), роли адвокации в работе сочиальных работников. Предложено описание программы подготовки будущих социальных работников к адвокационной деятельности. Поданы содержание, цели и задачи программы учебной дисциплины «Технологии социальной адвокации».

K ключевым темам программы отнесены следующие: адвокационная деятельность социального работника; методы социальной адвокации; организация адвокационной кампании; социальная адвокация как инструмент защиты прав и свобод граждан.

Приведены примеры практических работ и самостоятельных заданий, целью которых является закрепление студентами знаний по пройденному теоретическому материалу.

Ключевые слова: сочиальный работник, сочиальная работа, адвокация, адвокационная деятельность, социальная услуга представительства интересов, технологии социальной адвокации.

\section{SUMMARY}

Lekholetova Maryna, Liakh Tetiana. Preparing Future Social Workers for Advocacy.

Experts of the social sector often consider advocacy (representation of interests) as a part of individual social work, which is mainly used to solve certain legal issues. Therefore, the article aims to examine the essence of representation of interests (advocacy), the role of advocacy in duties of social workers and experience of preparing future social workers for advocacy at the Institute of Human Sciences of Borys Grinchenko Kyiv University.

This paper describes the program of preparation of future social workers for advocacy. It dwells on the content, goals, and objectives of the course "Technology of Social Advocacy". The purpose of teaching the course "Technology of Social Advocacy" is to promote development of professional competence of future social workers, provide theoretical knowledge of social advocacy technologies, as well as develop practical skills in organizing social advocacy campaigns. 
The key topics of the program include advocacy of a social worker; methods of social advocacy; organization of an advocacy campaign; and social advocacy as a tool for protecting the rights and liberties of citizens. The paper covers examples of practical works and self-study tasks suggested for broadening students' knowledge of the theoretical material.

It is indicated, that as a result of completing the course, future social workers will develop the following key competences: to select and apply various methods of social advocacy, to develop programs of advocacy campaigns; to apply knowledge in practical situations and make informed decisions; to initiate social changes aimed at improving social welfare.

Further research into determining the level of formation of knowledge and skills of advocacy by future social workers upon completion of the course "Technologies of Social Advocacy" would be of interest.

Key words social worker, social work, advocacy, social service of representation of interests, social advocacy technologies.

УДК 378.147

Олена Мартиненко

Сумський державний педагогічний університет імені А. С. Макаренка ORCID ID 0000-0002-8287-0573

Ярослав Чкана

Сумський державний педагогічний університет імені А. С. Макаренка ORCID ID 0000-0003-3667-3584

Ольга Удовиченко

Сумський державний педагогічний університет імені А. С. Макаренка ORCID ID 0000-0002-3401-3251

DOI 10.24139/2312-5993/2020.02/144-153

\section{УПРАВЛІННЯ САМОСТІЙНОЮ РОБОТОЮ МАЙБУТНІХ УЧИТЕЛІВ МАТЕМАТИКИ У ВІРТУАЛЬНОМУ НАВЧАЛЬНОМУ СЕРЕДОВИЩІ ЧЕРЕЗ ВИКОРИСТАННЯ ЕЛЕКТРОННОЇ ВЕРСІЇ РОБОЧОГО ЗОШИТУ}

У статті досліджено питання управління самостійною роботою студентів під час дистанційного навчання студентів фрізико-математичних фракультетів педагогічних університетів. Уточнено поняття самостійної роботи студентів під час дистанційного навчання. Виділено особливості математичних дисциплін, що впливають на планування та організацію самостійної роботи студентів. Запропоновано використання електронної версії робочого зошита з математичного аналізу для забезпечення самостійної роботи студентів в інформаційно-освітньому середовищі університету, показано доцільність та ефективність роботи за ним.

Ключові слова: самостійна робота студентів, дистанційне навчання, електронна версія робочого зошиту, математичні дисципліни.

Постановка проблеми. Якісна освіта $€$ тим фактором, що визначає економічний та соціальний розвиток сучасного суспільства. Однією 3 характерних її особливостей $\epsilon$ створення умов для вибору кожним студентом власної траєкторії навчання, що відповідає його потребам та професійним цілям і зумовлює особистісний розвиток. 